\title{
Klinik ve Çevresel Örneklerden Elde Edilen Aspergillus fumigatus İzolatlarında Azol Direncinin Fenotipik ve Genotipik Olarak Değerlendirilmesi
}

\section{Phenotypic and Genotypic Evaluation of Azole Resistance in Aspergillus fumigatus Isolates from Clinical and Environmental Specimens}

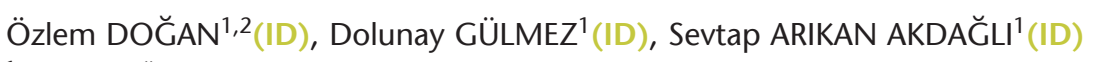 \\ ${ }^{1}$ Hacettepe Üniversitesi Tıp Fakültesi, Tıbbi Mikrobiyoloji Anabilim Dalı, Ankara. \\ ${ }^{1}$ Hacettepe University Faculty of Medicine, Department of Medical Microbiology, Ankara, Turkey. \\ ${ }^{2}$ Koç Üniversitesi Tıp Fakültesi, Enfeksiyon Hastalıkları ve Klinik Mikrobiyoloji Anabilim Dalı, İstanbul. \\ ${ }^{2}$ Koc University Faculty of Medicine, Department of Infectious Diseases and Clinical Microbiology, Istanbul, Turkey.
}

* Bu çalışma, Hacettepe Üniversitesi Bilimsel Araştırma Projeleri Koordinasyon Birimi tarafından desteklenmiştir (Proje Kodu: 2088.2014).

Makale Atıfı: Doğan Ö, Gülmez D, Arıkan Akdağlı S. Klinik ve çevresel örneklerden elde edilen Aspergillus fumigatus izolatlarında azol direncinin fenotipik ve genotipik olarak değerlendirilmesi. Mikrobiyol Bul 2020;54(2):291-305.

\section{öz}

Aspergillus fumigatus bağışıkıı sistemi baskılanmış konakta yüksek mortalite ile seyreden invaziv aspergillozun yanı sıra kronik pulmoner aspergillozu da içine alan farklı klinik tablolara neden olabilmektedir. Vorikonazol, aspergilloz tedavisinde ilk sırada tercih edilmesi önerilen antifungal ilaçtır. Vorikonazolün de içinde yer aldığı azol grubu ilaçlar, cyp51A geni tarafından kodlanan 14- $\alpha$ demetilaz enzimini inhibe eder. Son yıllarda yapılan çalışmalarda dünyada farklı merkezlerde çevresel ve klinik A.fumigatus izolatlarında artan azol direnci dikkati çekmektedir. Direnç gelişiminde iki farklı mekanizma öne sürülmüştür. Bunlardan ilki, klinikte uzun süreli azol kullanımına bağlı ortaya çıkan dirençtir. Bu yol ile gelişen azol direncinden genellikle cyp51A genindeki nokta mutasyonları sorumludur. İkinci mekanizma ise tarımda fungisit olarak azol kullanımına bağı sekonder çevresel azol maruziyetidir. Uzun süreyle ve değişen konsantrasyonlarda azol bileşikleri ile temas, sporlanma sürecindeki A.fumigatus üzerinde seçici baskıya ve mutasyonlara neden olmaktadır. Azol direnci kazanan suşların doğada bulunması nedeniyle, duyarlı kişilerin bu suşları çevreden alarak enfekte olmaları mümkün olabilmektedir. Genotipik olarak incelendiğinde çevresel direnç kazanan bu izolatlarda genellikle cyp51A geninde 98. kodondaki nokta mutasyonuna ek olarak promotor bölgede "tandem repeat" (TR34/L98H) saptanmıştır. Bu çalışmanın amacı, Hacettepe Üniversitesi Tıp Fakültesi Hastanesinde klinik örneklerden ve hastane çevresindeki peyzaj alanlarından izole edilen A.fumigatus izolatlarında azol direnç durumunun fenotipik ve genotipik yöntemlerle araştırılmasıdır. Morfolojik özelliklerin incelenmesini takiben termotolerans testi ile A.fumigatus sensu stricto olarak tanımlanan izolatlarda azol duyarlıık durumunun saptanması için agar tarama testi uygulanmış, azol içeren plakların herhangi birinde üreme olan izolatlarda "European Committee on Antimicrobial Susceptibility Testing" 
referans mikrodilüsyon yöntemi ile minimum inhibitör konsantrasyonu (MiK) değerleri belirlenmiştir. Ayrıca seçili izolatlarda cyp51A geni dizisi incelenerek mutasyon analizi yapılmıştır. Çalışmaya klinik örneklerden 483, çevre örneklerinden 65 toprak A.fumigatus sensu stricto izolatı dahil edilmiştir. Klinik izolatların birinci grubu 1997-2015 yıllarına ait 215 izolattan oluşmuş ve retrospektif olarak test edilmiştir. İkinci grup ise A.fumigatus kompleksi için rutin azol agar tarama testinin yapıldığı 2016-2018 yıllarına ait 268 izolattan oluşmuştur. Tüm klinik izolatlar $(n=483)$ birlikte değerlendirildiğinde izolatlardan biri 2015 yılından önce, 10'u 2016-2018 yılları arasında olmak üzere 11 (\%2.3)'i itrakonazole dirençli, 5 (\%1)'i artmış maruziyette duyarlı (Intermediate-I) A.fumigatus izolatı saptanmıştır. Azole dirençli izolatlarda incelenen cyp51A geninde, Aspergillus izolatlarında azol direnci ile ilişkilendirilmiş mutasyonların hiçbiri saptanmamış ve bu dirençli izolatlarda, direnç ile ilişkisi henüz tam olarak aydınlatılamamış bazı polimorfizmler (Y46F, G89G, V172M, T248N, E255D, L358L, K427E, C454C, Y431D ve bir izolatta bu polimorfizme ek olarak Q141H) gösterilmiştir. Çalışmamızda A.fumigatus izolatlarında azol direnci düşük oranda (\%2.3) saptanmıştır. Saptanan polimorfizmlerin azol direncine olası etkisinin gösterilmesi ve yüksek azol MiK değerleri ile ilişkili diğer mekanizmaların aydınlatılması için ileri çalışmalara gereksinim olduğu düşünülmüştür. Ayrıca ülkemizde bir bölgeden yüksek azol direnci bildirilmiş olması nedeniyle, farklı bölgelerde azol direnç durumunun ve azol direnci oranı için aralığın belirlenmesi ve ülkemize özgü olabilecek direnç mutasyonlarının açığa çıkarılması amacıyla çok merkezli çalışmaların gerekli olduğu sonucuna varılmıştır.

Anahtar kelimeler: Aspergillus fumigatus; azol direnci; polimorfizm; agar tarama testi; European Committee on Antimicrobial Susceptibility Testing referans mikrodilüsyon testi.

\section{ABSTRACT}

Aspergillus fumigatus can cause different clinical manifestations including chronic pulmonary infections, as well as invasive aspergillosis which is highly mortal in the immunocompromised host. Azole antifungal drugs, voriconazole in particular, are the first-line recommended therapeutic regimen. Azoles inhibit 14- $\alpha$ demethylase enzyme encoded by the cyp51A gene. In recent years, increased azole resistance is observed among environmental and clinical A.fumigatus isolates. Two different mechanisms have been proposed for the development of resistance. The first one is the triggering of resistance as a result of long-term clinical azole use. Point mutations in cyp51A gene are generally responsible for this type of azole resistance. The second mechanism is incidental environmental azole exposure due to the use of azoles as agricultural fungicides. Contact with azoles for extended periods and at varying concentrations causes selective pressure and mutations on sporulating A.fumigatus. Since the resistant strains may persist in nature, susceptible individuals may be infected by acquisition of these strains from the environment. When genotypically examined, the cyp51A gene of the resistant isolates of environmental origin specifically presents with a tandem repeat in the promoter region in addition to the point mutation in codon 98 (TR34/L98H). The aim of this study was to investigate azole resistance rates in A.fumigatus strains isolated from clinical specimens and landscaping areas around Hacettepe University Faculty of Medicine Hospital by phenotypical and genotypical methods. Agar screening test was used as the initial test to detect azole resistance in isolates identified as A.fumigatus sensu stricto according to thermotolerance test results. For all strains that grew on any of the azole containing plates in agar screening test, minimum inhibitory concentration (MIC) values were determined by "European Committee on Antimicrobial Susceptibilitiy Testing" reference microdilution method for the confirmation of the resistance. In addition, cyp51A gene sequence was investigated in selected isolates and mutation analysis was performed. A total of 483 clinical and 65 environmental A.fumigatus sensu stricto isolates were included in the study. The first group of clinical isolates consisted of 215 strains isolated in 1997-2015, revived from stock and tested. The second group consisted of 268 strains belonging to the time period of 2016-2018, during which routine azole agar screening tests were performed for A.fumigatus isolates. When all isolates ( $\mathrm{n}=$ 483) were evaluated together, 11 isolates (1 before 2015 and 10 between 2016-2018), were found to be resistant to itraconazole (2.3\%). None of the mutations previously reported to be associated with azole resistance in Aspergillus strains that were detected in cyp51A sequence analysis, However, polymorphisms which are not (yet) fully elucidated in relation to the resistance (Y46F, G89G, V172M, T248N, E255D, L358L, K427E, C454C, Y431D and Q141H in one strain) were shown to exist in resistant isolates. These 
results have shown that the rate of azole resistance among clinical A.fumigatus isolates was low (2.3\%) in our center. Further studies are required to demonstrate the possible role of the detected polymorphisms on azole resistance and to clarify other mechanisms related with high azole MIC values. In addition, since high azole resistance has been reported from one region in our country, it has been concluded that multicenter studies are required to determine the azole resistance status and the range for the azole resistance ratio in different regions and to reveal resistance mutations that may be specific to our country.

Keywords: Aspergillus fumigatus; azole resistance; gene polymorphism; agar screening test; European Committee on Antimicrobial Susceptibility Testing reference microdilution method.

\section{Giriş}

Tüm dünyada mantar enfeksiyonlarının sıklığı, risk altındaki popülasyonun artışına bağlı olarak giderek artmaktadır ${ }^{1}$. Aspergillus enfeksiyonlarında klinik tablo konağın bağışıklık durumuna göre değişmektedir² ${ }^{2}$ Özellikle nötropenik hastalarda yüksek mortalite ile seyreden invaziv aspergilloz öne çıkmakta iken, kistik fibrozis ve astım gibi kronik akciğer hastalığı olanlarda alerjik bronkopulmoner aspergilloz önemli sorun yaratmaktadır. Öte yandan, geçirilmiş akciğer tüberkülozu veya sarkoidoz gibi hastalıklar sonrası kaviter pulmoner sekelleri olan hastalarda aspergilloma olarak isimlendirilen fungus topları gelişebilmektedir. Diyabet ve alkolizm gibi predispozan faktörlerin varlığında ise kronik pulmoner aspergilloz görülebilmektedir ${ }^{3}$.

Aspergillus enfeksiyonlarında etken olarak farklı türler izole edilebilmektedir. Doğada 150'nin üzerinde tür bulunmakla birlikte, klinik örneklerde bazı türler ön plana çıkmaktadır. Günümüzde Aspergillus cinsinde bulunan türler morfolojik yakınlıklarına göre komplekslere ayrılmıştır. Rutin klinik laboratuvarlarda tanımlama daha çok morfolojik özelliklere dayandığından, genellikle tür kompleksi düzeyinde ayrım yapılabilmekte olup, bu düzeyde tanımlama rutin amaçlı olarak yeterli olmaktadır. Tür düzeyinde tanımlama için morfolojik özellikler yetersiz kalmakta ve genotipik yöntemler gerekmektedir. Ancak, en sık rapor edilen A.fumigatus kompleksi içinde yine en sık gözlenen tür olan A.fumigatus sensu stricto, termotolerans testi ile ayrılabilmektedir. Kompleks içindeki türlerin ayrılması, farklı antifungal duyarlılık profilleri gözlenmesi nedeniyle tedavinin yönlendirilmesinde önemli rol oynayabilmektedir ${ }^{4}$. Örneğin A.fumigatus kompleksi içinde, antifungal ilaçlara direnç gösteren Aspergillus lentulus gibi türler de yer almaktadır ${ }^{5}$. Kompleks içindeki kriptik türlerin genotipik ayrımında ITS geninin yanı sıra $\beta$-tübülin, kalmodülin ya da rodlet A genlerine ait diziler kullanılabilmektedir ${ }^{6-8}$.

Aspergilloz tedavisinde bugün birçok uluslararası bilimsel dernek ve komite azol grubu antifungal ilaçları profilaksi ve tedavide önermektedir ${ }^{8,9}$. Ancak son yıllarda tüm dünyada A.fumigatus izolatlarında artan azol direnci dikkati çekmektedir ${ }^{10}$. A.fumigatus izolatlarında azol direnci ilk kez 1997 yılında saptanmış ve ardından yayımlanan çeşitli direnç bildirimlerinin sonuçları genotipik olarak incelendiğinde azol direncine, ilacın hedef enzimi olan $14 \alpha$-demetilazı (lanosterol demetilaz) kodlayan cyp51A genindeki nokta mutasyonlarının neden olduğu gösterilmiştir ${ }^{11,12}$. Hollanda'da 1994-2007 yıllarında yapılan bir çalışmada ${ }^{13}$ yıllar içinde artan itrakonazol direnci dikkati çekmiş, dirençli izolatların çok büyük bir bölümünde aynı değişimin olduğu görülmüştür. Bu değişim- 
de, cyp51A geninde nokta mutasyonu (L98H) ile birlikte genin promotor bölgesinde 34 aminoasitlik bölgesinin çift kopya oluşunun rolü bulunmaktadır. Dirençten sorumlu bu değişim, "TR34/L98H" olarak isimlendirilmiştir. Takip eden sürede bu mekanizma hemen tüm Avrupa ülkelerinde hasta örneklerinde saptanmıştır. Bu direnç mekanizmasının kaynağı incelendiğinde, tarımda fungisit olarak kullanılan demetilaz inhibitörlerinin medikal azol ilaçlara benzer kimyasal yapıları ile direnci indükleyebileceği görüşü ortaya çıkmıştır. Bu fungisitlerin yapısal olarak medikal azollere benzerlik göstermesi, doğada çok miktarda spor oluşturan A.fumigatus'ta direncin ortaya çıkmasına neden olmakta, ortaya çıkan azol dirençli suşlar doğada kalıcı olabilmekte ve daha önce hiç azol almamış hastalarda hastalık etkeni olarak ortaya çıkmaları mümkün olmaktadır ${ }^{14}$. Bu nedenle, azol direncinden sorumlu olan TR34/L98H mutasyonu klinik örneklerin yanı sıra çevresel örneklerde de yaygın olarak saptanmıştır. Ayrıca, kronik aspergillozu olan hastalarda uzun süreli azol kullanımı ile de direnç gelişebilmekte, bu durumda farklı mutasyonlar gözlenmektedir ${ }^{12,15}$. Dünyada birçok farklı bölgede A.fumigatus izolatlarında sıklığı değişen oranda azol direnci bildirilmeye başlanmıştır ${ }^{16}$. Bu nedenle, ülkede ve merkezlerde A.fumigatus izolatlarındaki azol direncinin sıklığının saptanması ve direnç mekanizmasının genetik temellerinin aydınlatılması, güncel tanı ve tedavi kılavuzlarında önerilmektedir ${ }^{8}$. Bu çalışmada, hastanemizde klinik izolatlardan ve hastane çevresindeki doğal ortamlardan izole edilmiş A.fumigatus izolatlarında azol duyarlılığının saptanması ve direnç varlığında olası mekanizmaların moleküler yöntemlerle araştırılması amaçlanmıştır.

\section{GEREÇ ve YÖNTEM}

\section{Klinik Izolatlar}

Birinci grup: Hacettepe Üniversitesi Tıp Fakültesi Tıbbi Mikrobiyoloji Anabilim Dalı Mikoloji Laboratuvarında hasta örneklerinden 1997-2015 yılları arasında izole edilmiş ve $-80^{\circ} \mathrm{C}^{\prime}$ de saklanmış A.fumigatus sensu stricto izolatları çalışmaya alındı. Her hastadan bir izolat çalışmaya dahil edildi.

İkinci grup: Mikoloji Laboratuvarında 2016-2018 yıllarında izole edilen tüm A.fumigatus kompleksi izolatları termotolerans testine alınarak test sonucunda A.fumigatus sensu stricto olduğu saptanan izolatlara azol direnci için agar tarama testi yapıldı. Agar tarama testinde üreme pozitif bulunan izolatların "European Committee on Antimicrobial Susceptibility Testing (EUCAST)" mikrodilüsyon referans yöntemi ile azol minimum inhibitör konsantrasyonu (MiK) değerleri belirlendi. Azollere duyarlı ve dirençli izolatların eş zamanlı olarak bir hastada bulunabilmesi ve kronik aspergillozu olan hastalarda zaman içinde direnç gelişimi gözlenebilmesi nedeniyle, aynı hastanın tekrarlayan örneklerinden soyutlanan veya tek bir örneğinden izole edilen farklı makroskobik morfolojiye sahip izolatları için rutin olarak agar tarama testleri yapıldı ve gereken izolatlarda mikrodilüsyon duyarlılık testi uygulandı. Bu çalışmada, bir hastaya ait tekrarlayan izolatlar çıkarılarak (aynı hastadan izole edilen suşlar arasında > 1 ay olacak 
şekilde ve invaziv aspergilloz şüphesi olanlarda farklı örneklerden bir tanesi dahil edilerek) kullanıldı.

\section{Çevre İzolatları}

Hacettepe Üniversitesi Erişkin, Çocuk ve Onkoloji Hastaneleri ve otoparkların çevresindeki peyzaj alanlarından toprak örnekleri toplandı. Hasta geçişinin yoğun olduğu bölgelerde olası azole dirençli suşların saptanması amaçlanarak direnç oranı belirleyebilmek için alan taraması yapılmadı. Örnekler, daha önce literatürde bildirilmiş yöntemler temel alınarak izole edildi ${ }^{7,14}$. Seçilen alandan alınan $2 \mathrm{~g}$ toprak, \%0.1 Tween 20 ve $0.04 \mathrm{~g} / \mathrm{L}$ gentamisin içeren $5 \mathrm{ml}$ steril serum fizyolojik ile karıştırılarak bu süspansiyondan 100 $\mu \mathrm{l}$ alınıp Sabouraud dekstroz agara (SDA) ekim yapıldı ${ }^{7}$. Plaklar $37^{\circ} \mathrm{C}^{\prime}$ de inkübe edilerek 24, 48 ve 72 saat sonra üremelerin kontrolü yapıldı. Morfolojik olarak A.fumigatus kompleksine benzeyen tüm koloniler saflaştırıldıktan sonra A.fumigatus sensu stricto olarak tanımlanan izolatlar çalışmaya dahil edildi.

\section{İzolatların Tanımlanması}

İzolatların tanımlanmasında, makroskobik ve mikroskobik morfolojik özellikler ve termotolerans testi kullanıldı ${ }^{7,8,17}$.

\section{Termotolerans Testi}

Test edilecek izolatın üç gün inkübasyonu sonrasında yeterli üreme göstermiş olan bir kolonisi, \%0.1 Tween 20 içeren steril distile su ile ıslatılarak eküvyon çubuğu yardımı ile bir miktar konidyum alınıp SDA'ya ekildi. Ekilen plaklar çalışmanın ilk aşamasında $48^{\circ} \mathrm{C}^{\prime} \mathrm{de}, 2016$ yılı ve sonrasında ise önerilen standartlardaki değişiklik göz önüne alınarak $50^{\circ} \mathrm{C}^{\prime}$ de inkübe edildi ${ }^{7,8}$. Üremeler 24 ve 48. saatte kontrol edildi. Üreme gözlenen izolatlar A.fumigatus sensu stricto olarak değerlendirildi.

\section{Azol Agar Tarama ve Antifungal Duyarlılık Testleri}

Çalışmaya alınan izolatlar önce azol agar tarama testi ile incelendi. İtrakonazol agar tarama plaklarında üreme gözlenen izolatlarda EUCAST önerileri doğrultusunda azol Mik değerleri saptandı ${ }^{18,19}$. Kalite kontrolü için Aspergillus flavus ATCC 204304 ve azol direnci yönünden pozitif kontrol olarak daha önce Uludağ Üniversitesi Tıp Fakültesi Tıbbi Mikrobiyoloji Anabilim Dalı Mikoloji Laboratuvarında izole edilen ve TR34/L98H direnç mekanizmalarını içerdiği gösterilmiş bir izolat (suş 12868) kullanıldıı,20.

Agar tarama testinde itrakonazol $(4 \mu \mathrm{g} / \mathrm{ml})$, vorikonazol $(1 \mu \mathrm{g} / \mathrm{ml})$, posakonazol $(0.5 \mu \mathrm{g} / \mathrm{ml})$ ilave edilmiş \%2 glukozlu RPMI agar kullanıldı ${ }^{21}$. Önerilen değişiklikler göz önüne alınarak, Mayıs 2018 tarihinden itibaren vorikonazol miktarı $2 \mu \mathrm{g} / \mathrm{ml}$ 'ye çıkarıl$\mathrm{d}^{18,22,23}$. Bu amaçla, 48-72 saat inkübasyon sonrasında bir koloniden \%0.1 Tween 20 içeren steril distile su ile ıslatılmış eküvyon yardımı ile bir miktar konidyum alınıp, tarama plaklarına ve eş zamanlı olarak antifungal içermeyen kontrol plağına ekim yapıldı. Plaklar, oda sıcaklığında kuruduktan sonra $35^{\circ} \mathrm{C}^{\prime}$ de 24 ve 48 saat inkübasyon sonrasında 
incelendi. Agar tarama yöntemi ile azol içeren plakların herhangi birinde üreme saptanan izolatlar, antifungal duyarlılık testine alındı.

Antifungal duyarlılık testleri, konidyum oluşturan küf mantarları için hazırlanan EUCAST kılavuzunun önerdiği biçimde mikrodilüsyon yöntemiyle gerçekleştirildi ${ }^{19}$. EUCAST tarafından önerilen klinik direnç sınır değerleri temel alınarak, itrakonazol ve vorikonazol için $\geq 4 \mu \mathrm{g} / \mathrm{ml}$, posakonazol için ise $>0.5 \mu \mathrm{g} / \mathrm{ml}$ olan MiK değerleri ilgili ilaca direnç olarak yorumlandı. Mik değeri itrakonazol ve vorikonazol için $2 \mu \mathrm{g} / \mathrm{ml}$, posakonazol için ise $0.25 \mu \mathrm{g} / \mathrm{ml}$ olduğunda, artmış maruziyette duyarlı (intermediate) olarak alındı. Herhangi bir azol MiK değerinin direnç sınır değeri sınırında veya üzerinde bulunması durumunda, antifungal duyarlılık testi doğrulama amacıyla tekrar edildi.

\section{Dizi ve Mutasyon Analizi}

Azol agar tarama testinde itrakonazol plaklarınde üreme gözlenen ve Mik değeri duyarlılık sınırını aşan ( $\geq 2 \mu \mathrm{g} / \mathrm{ml}$ ) izolatlar ile, negatif kontrol olarak her üç azol için Mik değerleri duyarlılık sınırının altında bulunan bir izolat ve pozitif kontrol olarak TR34/ L98H mutasyonu varlığı bilinen suş 12868 için cyp51A geni dizi analizi gerçekleştirildi ve elde edilen dizilerde mutasyon analizi yapıldı (Refgen Biyoteknoloji, Ankara). Polimeraz zincir reaksiyonu (PCR) ile cyp51A geninin çoğaltılması için F - 5'-ATG GTG CCG ATG CTA TGG-3' ve R - 5'-CTG TCT CAC TTG GAT GTG-3' primerleri kullanıldı ${ }^{24}$. PCR ile elde edilen ürüne ait diziler, referans cyp51A dizisi ile karşılaştırıldı (GenBankası erişim no. AF338659). Dizi ve mutasyon saptama için BioEdit Sequence Alignment Editor v7.2 programı ClustalW analizi kullanıldı.

\section{BULGULAR}

1997-2015 yılları arasında izole edilen 215 A.fumigatus sensu stricto izolatı birinci grup olarak çalışmaya alınmıştır.

2016-2018 yılları arasında tüm klinik örneklerden azol tarama testi ve/veya mikrodilüsyon testi yapılan 324 A.fumigatus kompleksine ait izolattan termotolerans testi ile A.fumigatus sensu stricto olarak tanımlanan 268'i ikinci grup olarak değerlendirmeye alınmıştır.

Çalışmaya dahil edilen 483 klinik A.fumigatus sensu stricto izolatının örneklere göre dağılımları Tablo I'de özetlenmiştir. En sık alt solunum yollarından $(n=313, \% 64.8)$ üreme saptanmıştır.

Çalışmaya alınan 483 A.fumigatus sensu stricto suşundan 10'u ikinci grupta olmak üzere 34'ü itrakonazol içeren plakta, bunlardan bir kısmı da vorikonazol ve/veya posakonazol içeren plaklarda üremiştir. Bu 34 izolata ait azol agar tarama ve EUCAST referans mikrodilüsyon yöntemi ile elde edilen MiK değerleri Tablo II'de verilmiştir.

Agar tarama plaklarında üreme gözlenen 34 izolatın 22'si sadece itrakonazol plaklarında üremiştir. Bunlardan 4'ü, mikrodilüsyon ile her 3 azole de duyarlı bulunmuştur. 


\begin{tabular}{|c|c|c|c|c|c|c|}
\hline \multirow[b]{2}{*}{ Örnek } & \multicolumn{2}{|c|}{ Birinci grup } & \multicolumn{2}{|c|}{ İkinci grup } & \multicolumn{2}{|c|}{ Toplam } \\
\hline & Sayı & $\%$ & Sayı & $\%$ & Sayı & $\%$ \\
\hline Alt solunum yolu örnekleri ${ }^{1}$ & 125 & 58.1 & 188 & 70.1 & 313 & 64.8 \\
\hline Steril vücut sıvıları ${ }^{2}$ & 17 & 7.9 & 38 & 14.2 & 55 & 11.4 \\
\hline Doku $^{3}$ & 40 & 18.6 & 14 & 5.2 & 54 & 11.2 \\
\hline Püy ${ }^{4}$ & 17 & 7.9 & 16 & 6.0 & 33 & 6.8 \\
\hline Diğer $^{5}$ & 16 & 7.4 & 12 & 4.5 & 28 & 5.8 \\
\hline Toplam & 215 & 100.0 & 268 & 100.0 & 483 & 100.0 \\
\hline
\end{tabular}

İtrakonazol plağında üreyen 34 izolatın 16'sında (MiK $\geq 2 \mu \mathrm{g} / \mathrm{ml}$ ), vorikonazol plağında üreyen 12 izolattan $11^{\prime}$ inde (MiK $\geq 2 \mu \mathrm{g} / \mathrm{ml}$ ) ve posakonazol plağında üreyen 6 suşun (MiK $\geq 0.25 \mu \mathrm{g} / \mathrm{ml}$ ) hepsinde MiK değerleri duyarlılık sınır değerinin üzerinde bulunmuştur. Vorikonazol plağında üreme gözlenmeden Mik değeri duyarlılık sınııını aşan izolat bulunmamakla birlikte, posakonazol plağında üreme olmadığı halde 14 izolat dirençli (MiK $\geq 0.5 \mu \mathrm{g} / \mathrm{ml}$ ) olmak üzere 24 izolatta MiK değerinin duyarlılık sınırını aştığı (MiK $\geq 0.25 \mu \mathrm{g} / \mathrm{ml}$ ) gözlenmiştir.

Hacettepe Üniversitesi Erişkin Hastanesi, Çocuk Hastanesi, Onkoloji Hastanesi ile hastane kompleksi içindeki otoparkların giriş ve etrafındaki çiçek ve ağaçlardan oluşan peyzaj alanlarından toplanan 100 toprak örneğinden elde edilen 65 A.fumigatus kompleksi izolatının tamamı termotolerans testi ile A.fumigatus sensu stricto olarak tanımlanmıştır.

Azol agar tarama testine alınan 65 toprak izolatından 12'sinde itrakonazol plaklarında üreme görülmüş, hiçbiri posakonazol ve vorikonazol kültür plaklarında ürememiştir. Buna karşın 1 izolatta vorikonazol, tüm izolatlarda posakonazol için duyarlılık sınır değerini aşan Mik değerleri saptanmıştır (Tablo III).

Seçilen bazı izolatlarda cyp51A geni dizisi analiz edilmiş ve mutasyon analizi sonuçları Tablo IV'te verilmiştir. Bunun için itrakonazol MiK değeri $\geq 2 \mu \mathrm{g} / \mathrm{ml}$ olan 6 hasta ve 8 toprak izolatının yanı sıra tüm azollere duyarlı bir klinik izolat (K7) ve posakonazol MiK değeri $0.5 \mu \mathrm{g} / \mathrm{ml}$ olan 1 toprak izolatı (T2) çalışılmıştır. DNA dizi analizi sonucunda, biri hariç tüm izolatlarda aynı patern belirlenmiş, yalnızca K16 izolatında diğer izolatlarda gözlenen polimorfizmlere ek olarak Q141H polimorfizmi tespit edilmiştir. İzolatların hiçbirinde daha önce tek başına azol direncine neden olduğu tanımlanmış olan TR34/L98H direnç mekanizması ya da diğer cyp51A mutasyonları gösterilememiştir. Pozitif kontrol olarak çalışmaya alınmış olan suş 12868 'de ise, beklendiği gibi TR34/L98H paterni yine saptanmıştır ${ }^{20}$. 


\begin{tabular}{|c|c|c|c|c|c|c|c|}
\hline \multirow[b]{2}{*}{ Örnek } & \multirow[b]{2}{*}{ Yıl } & \multicolumn{3}{|c|}{ Azol agar tarama testi sonuçları } & \multicolumn{3}{|c|}{ Antifungal duyarlıık testi sonuçları $(\mu \mathrm{g} / \mathrm{ml})$} \\
\hline & & İtrakonazol & Vorikonazol & Posakonazol & İtrakonazol & Vorikonazol & Posakonazol \\
\hline K1 & 2014 & Pozitif & Negatif & Negatif & 1 & 1 & 0.5 \\
\hline K2 & 2013 & Pozitif & Negatif & Negatif & 1 & 0.5 & 0.5 \\
\hline K3 & 2013 & Pozitif & Negatif & Negatif & 1 & 0.5 & 0.5 \\
\hline K4 & 2006 & Pozitif & Pozitif & Negatif & 2 & 1 & 1 \\
\hline K5 & 2007 & Pozitif & Negatif & Negatif & 1 & 1 & 0.25 \\
\hline K6 & 2008 & Pozitif & Pozitif & Pozitif & 4 & 2 & 1 \\
\hline K7 & 2005 & Pozitif & Negatif & Negatif & 0.25 & 0.25 & 0.06 \\
\hline $\mathrm{K} 8$ & 2000 & Pozitif & Negatif & Negatif & 0.5 & 1 & 0.25 \\
\hline K9 & 2002 & Pozitif & Negatif & Negatif & 0.5 & 1 & 0.25 \\
\hline K10 & 2003 & Pozitif & Negatif & Negatif & 2 & 1 & 0.5 \\
\hline K11 & 2006 & Pozitif & Negatif & Negatif & 0.5 & 0.5 & 0.06 \\
\hline K12 & 2013 & Pozitif & Negatif & Negatif & 0.5 & 0.5 & 0.25 \\
\hline K13 & 1998 & Pozitif & Negatif & Negatif & 0.25 & 0.5 & 0.125 \\
\hline K14 & 2005 & Pozitif & Negatif & Negatif & 0.5 & 0.5 & 0.125 \\
\hline K15 & 2006 & Pozitif & Negatif & Negatif & 0.5 & 0.5 & 0.125 \\
\hline K16 & 2013 & Pozitif & Negatif & Negatif & 2 & 1 & 0.5 \\
\hline K17 & 2002 & Pozitif & Negatif & Negatif & 1 & 0.5 & 0.25 \\
\hline K18 & 2014 & Pozitif & Negatif & Negatif & 0.5 & 0.5 & 0.25 \\
\hline K19 & 2005 & Pozitif & Negatif & Negatif & 0.5 & 0.5 & 0.25 \\
\hline K20 & 2014 & Pozitif & Negatif & Negatif & 1 & 1 & 0.25 \\
\hline K21 & 1999 & Pozitif & Negatif & Negatif & 1 & 0.5 & 0.25 \\
\hline K22 & 2013 & Pozitif & Negatif & Negatif & 2 & 1 & 1 \\
\hline K23 & 2013 & Pozitif & Negatif & Negatif & 2 & 0.5 & 0.5 \\
\hline K24 & 2001 & Pozitif & Negatif & Negatif & 1 & 0.5 & 0.25 \\
\hline K25 & 2016 & Pozitif & Pozitif & Pozitif & 8 & 4 & 1 \\
\hline K26 & 2016 & Pozitif & Pozitif & Pozitif & 8 & 4 & 1 \\
\hline K27 & 2017 & Pozitif & Pozitif & Pozitif & 8 & 4 & 2 \\
\hline K28 & 2017 & Pozitif & Pozitif & Pozitif & 8 & 4 & 1 \\
\hline K29 & 2018 & Pozitif & Pozitif & Negatif & 8 & 4 & 4 \\
\hline K30 & 2018 & Pozitif & Pozitif & Negatif & 8 & 4 & 2 \\
\hline K31 & 2018 & Pozitif & Pozitif & Negatif & 8 & 8 & 2 \\
\hline K32 & 2018 & Pozitif & Pozitif & Negatif & 8 & 8 & 2 \\
\hline K33 & 2018 & Pozitif & Pozitif & Negatif & 8 & 8 & 1 \\
\hline K34 & 2018 & Pozitif & Pozitif & Negatif & 8 & 4 & 0.5 \\
\hline
\end{tabular}




\begin{tabular}{|c|c|c|c|c|c|c|}
\hline \multirow[b]{2}{*}{ Örnek } & \multicolumn{3}{|c|}{ Azol agar tarama testi sonuçları } & \multicolumn{3}{|c|}{ Antifungal duyarlılık testi sonuçları $(\mu \mathrm{g} / \mathrm{ml})$} \\
\hline & İtrakonazol & Vorikonazol & Posakonazol & İtrakonazol & Vorikonazol & Posakonazol \\
\hline T1 & Pozitif & Negatif & Negatif & $8-4$ & 2 & 1 \\
\hline $\mathrm{T} 2$ & Pozitif & Negatif & Negatif & 1 & 0.5 & 0.5 \\
\hline T3 & Pozitif & Negatif & Negatif & 2 & 1 & 1 \\
\hline $\mathrm{T} 4$ & Pozitif & Negatif & Negatif & $8-4$ & $2-1$ & 1 \\
\hline T5 & Pozitif & Negatif & Negatif & $8-4$ & $2-1$ & 1 \\
\hline T6 & Pozitif & Negatif & Negatif & $8-4$ & $2-1$ & 1 \\
\hline T7 & Pozitif & Negatif & Negatif & $8-4$ & $2-1$ & 1 \\
\hline T8 & Pozitif & Negatif & Negatif & $>8-4$ & $2-1$ & 1 \\
\hline T9 & Pozitif & Negatif & Negatif & $8-4$ & $2-1$ & 1 \\
\hline T10 & Pozitif & Negatif & Negatif & $8-4$ & $2-1$ & 1 \\
\hline T11 & Pozitif & Negatif & Negatif & $>8-8$ & $2-1$ & 1 \\
\hline T12 & Pozitif & Negatif & Negatif & 1 & 0.5 & 0.25 \\
\hline
\end{tabular}

\begin{tabular}{|lllllllllll}
\hline \multicolumn{7}{ll}{ Tablo IV. Klinik ve Çevresel izolatlarda cyp51A Geninde Saptanan Polimorfizmler* } \\
\hline Örnek & \multicolumn{7}{c}{ Saptanan polimorfizmler } \\
\hline K4 & Y46F & G89G & V172M & T248N & E255D & L358L & K427E & C454C & Y431D & \\
K6 & Y46F & G89G & V172M & T248N & E255D & L358L & K427E & C454C & Y431D & \\
K7 & Y46F & G89G & V172M & T248N & E255D & L358L & K427E & C454C & Y431D & \\
K10 & Y46F & G89G & V172M & T248N & E255D & L358L & K427E & C454C & Y431D & \\
K16 & Y46F & G89G & V172M & T248N & E255D & L358L & K427E & C454C & Y431D & Q141H \\
K22 & Y46F & G89G & V172M & T248N & E255D & L358L & K427E & C454C & Y431D & \\
K23 & Y46F & G89G & V172M & T248N & E255D & L358L & K427E & C454C & Y431D & \\
T1 & Y46F & G89G & V172M & T248N & E255D & L358L & K427E & C454C & Y431D & \\
T2 & Y46F & G89G & V172M & T248N & E255D & L358L & K427E & C454C & Y431D & \\
T4 & Y46F & G89G & V172M & T248N & E255D & L358L & K427E & C454C & Y431D & \\
T5 & Y46F & G89G & V172M & T248N & E255D & L358L & K427E & C454C & Y431D & \\
T6 & Y46F & G89G & V172M & T248N & E255D & L358L & K427E & C454C & Y431D & \\
T7 & Y46F & G89G & V172M & T248N & E255D & L358L & K427E & C454C & Y431D & \\
T8 & Y46F & G89G & V172M & T248N & E255D & L358L & K427E & C454C & Y431D & \\
T9 & Y46F & G89G & V172M & T248N & E255D & L358L & K427E & C454C & Y431D & \\
T10 & Y46F & G89G & V172M & T248N & E255D & L358L & K427E & C454C & Y431D & \\
T11 & Y46F & G89G & V172M & T248N & E255D & L358L & K427E & C454C & Y431D & \\
\hline
\end{tabular}

* K7 dışındaki suşlarda en az bir azol için duyarlılık sınır değerini aşan minimum inhibitör konsantrasyonu değerleri saptanmıştır. 


\section{TARTIŞMA}

Aspergillus enfeksiyonlarında etken olarak en sık A.fumigatus sensu stricto karşımıza çıkmaktadır. Yakın zamana kadar klinik mikrobiyoloji laboratuvarlarında tür kompleksi düzeyinde tanımlanma yeterli görülmekteyse de, A.fumigatus'ta sekonder azol direnci gösterilmesi ve azole dirençli türlerin tedavi sorunlarına yol açması nedeniyle A.fumigatus sensu stricto'nun diğer kompleks üyesi türlerden ayrılması önem kazanmıştır ${ }^{6}$.

A.fumigatus'da sekonder azol direnci ilk tanımlandığı 1997 yılından itibaren giderek artmış ve dünyada birçok bölgede gösterilmiştir. Yapılan çok ve tek merkezli sürveyans çalışmalarında A.fumigatus'ta azol direnci; çalışmaya alınan hasta popülasyonuna ve izolatların klinik veya çevresel kökenli olmasına göre \%2-28 değişen oranlar arasında saptanmış, tarım ve çiçekçiliğin yaygın olduğu bölgelerde bu oranın daha yüksek olduğu tespit edilmiştir ${ }^{12,25}$. Azol grubu antifungal ilaçların özellikle kök hücre nakli yapılan ve nötropenik hastalarda tedavi ve profilaksi amacıyla kullanılıyor olması nedeniyle, artmakta olan direnç oranları kaygı vericidir ${ }^{26}$. Azol direncinin saptanması için önerilen referans antifungal duyarlılık testlerinin rutin klinik mikrobiyoloji laboratuvarlarında uygulanmasında karşılaşılan güçlükler nedeniyle azol agar tarama testi geliştirilmiştir ${ }^{21}$. İtrakonazol, vorikonazol ve posakonazol içeren agar tarama plakları ile yapılan çok merkezli bir çalışma ${ }^{18}$, bu yöntemin duyarlılık ve özgüllüğünün \%99 olduğunu bildirmiştir. Aynı çalışmada sadece itrakonazol ve vorikonazol plakları ile duyarlılığın aynı seviyede kaldığı belirtilmiştir. Bu yöntem, EUCAST E.Def 10.1 dokümanında standart referans yöntem olarak önerilmektedir ${ }^{23}$. Bu çalışmada azol direnci yönünden tarama için her üç azol plağı da kullanılmış, herhangi bir plakta üreme gözlendiğinde referans yöntem ile MiK değerleri belirlenmiştir. Şüpheli izolatların tamamı itrakonazol plaklarında, bazıları ek olarak vorikonazol ve/veya posakonazol plaklarında da üreyebilmiştir.

Azole direnç oranları dünyanın farklı bölgelerinde farklılıklar göstermekte ve \%20 ve daha yüksek oranlara ulaşabilmektedir ${ }^{27}$. Ülkemizde Bursa ilinde 1999-2012 yılları arasında izole edilmiş klinik A.fumigatus izolatlarında \%10.2 oranında itrakonazol direnci bildirilmiştir ${ }^{20}$. Bu çalışmada, 1997-2018 yıllarına ait 483 izolattan 11 (\%2.3)'inde itrakonazole direnç saptanmıştır.

cyp51A geninde azol direnci ile ilişkili birçok nokta mutasyonu saptanmış olsa da, en bilinen mutasyonlar G54, P216, F219, M220 ve G448 olarak tanımlanmıştır. Bu mutasyonlar enzimin "hot spot" bölgeleri olarak tanımlanan, ilacın enzime bağlanma bölgesi gibi ilaç enzim ilişkisinin önemli olduğu bölgelerde meydana gelmektedir. Bu bölgelerde mutasyon oluştuğunda azol grubu antifungaller lanosterol demetilaz enzimiyle etkileşememekte; bu durum hastanın kliniğine izole itrakonazol, posakonazol veya vorikonazol direnci ya da tüm azollere karşı panazol direnci olarak yansıyabilmektedir ${ }^{16}$. Bu çalışmada sözü edilen mutasyonlar gözlenmemiş, bir izolatta Q141H mutasyonu saptanmıştır. Snelders ve arkadaşları ${ }^{24}$ tarafından yapılan bir çalışmada Q141H çevre kaynaklı panazol dirençli bir izolatta TR34/L98H mutasyonu ile birlikte bulunmuştur. Aynı araştırma gru- 
bunun yaptığı bir başka çalışmada, toprak örneğinde TR34/L98H mutasyonu ile birlikte dirençli bir izolatta da Q141 H saptanmıştır ${ }^{28}$. Q141 H'nin tek başına azol direnci ile ilişkilendirilip ilişkilendirilemeyeceği ile ilgili henüz kesin veri bulunmamaktadır.

Tarımda azol fungisit kullanımına bağlı doğada meydana gelen azol direncinin ortaya çıkmasına neden olan en bilinen değişim, TR34/L98H değişimi ve mutasyonudur ${ }^{14}$. Bu mekanizma ile ortaya çıkan dirençte, hedef modifikasyonu ve buna bağlı ilaç enzim etkileşimi bozulmasının yanı sıra, promotor bölgedeki 34 baz çiftlik bölgenin çift kopya oluşu da rol oynamaktadır ${ }^{12}$. Son yıllarda, TR34/L98H mutasyonuna ilave olarak TR46/Y121F/ T289A mutasyonu da benzer şekilde çevresel kaynaklı direnç olgularıyla ilişkilendirilmiştir. Bu paternin görüldüğü olgularda vorikonazol direncinin öncelikli olması dikkat çekmektedir $^{29}$. Gen bölgesinde aminoasit değişikliği olmaksızın sadece promotor bölgede "tandem repeat" ile kendini gösteren TR53 paterni de benzer olarak çevresel kaynaklı direnç ile ilişkilendirmektedir ${ }^{30}$.

Ülkemizde Bursa ilinde hasta izolatlarında yapılmış olan çalışmada itrakonazol direnci \%10.2 bulunmuş, dirençli izolatlar incelenmiş ve \%86.8'inde TR34/L98H mutasyonu saptanmıştır ${ }^{20}$. Çalışmamızda, A.fumigatus sensu stricto izolatlarında bu mutasyona rastlanmamıştır. Bursa ilinde tarım faaliyetlerinin yoğun olması, bu bölgede Ankara ili ile karşılaştırıldığında iklimin daha ılıman ve yağışlı olması ve bu iklim koşulları nedeniyle tarım alanlarında fungisitlerin daha sık kullanılabiliyor olması gibi faktörlerin iki çalışma sonuçları arasındaki farkı açıklayabileceği düşünülmüştür. Ancak, Bursa'da yapılan bu çalışmanın klinik örneklerle sınırlı olması ve çevresel izolatların dahil edilmemiş olması nedeniyle direncin kaynağına yönelik bir görüş oluşmamıştır. Ülkemizde Aspergillus azol direncinin yaygınlığının ve ortaya çıkış yolunun incelenebilmesi için ülkenin farklı bölgelerinden elde edilen klinik ve çevresel Aspergillus izolatlarında yapılacak çok merkezli çalışmalara intiyaç bulunmaktadır.

Yapılan çalışmalarda klinik ve çevresel izolatlarda ortaya çıkan, bu iki farklı azol direnç mekanizmasını işaret eden belirlenmiş aminoasit değişimlerine ek olarak bir dizi cyp51A geni mutasyonu/polimorfizmi saptanmıştır. Bunlar hep birlikte veya farklı kombinasyonlarda olmak üzere Y46F, G89G, V172M, T248N, E255D, L358L, K427E, C454C mutasyonları olarak tanımlanmıştır ${ }^{7}$. Bu çalışmamızda da benzer olarak hem çevresel hem de klinik izolatlarda bu polimorfizmler saptanmıştır (Tablo IV). Literatürde bu polimorfizmlerin hem duyarlı hem de dirençli izolatlarda saptanabildiği gösterilmiştir. Bazı çalışmalarda, bu polimorfizmler yükselmiş azol MiK değerleri ile ilişkilendirilmişse de direnç ile ilişkileri henüz tam olarak aydınlatılamamıştır ${ }^{14}$. Çalışmamızda da çevresel ve klinik örneklerde Mik değeri yüksek izolatların yanı sıra duyarlı kontrol suşunda da bu polimorfizmlerin varlığı belirlenmiştir. Bu durum, bizim izolatlarımızda, farklı bir direnç mekanizmasının geçerli olabileceğini düşündürmektedir ${ }^{31}$. Alanio ve arkadaşları tarafından yapılan bir çalışmada ${ }^{15}$ bu polimorfizmlerin saptandığı izolatlarda itrakonazol MiK değerlerinin duyarlıık eşik değerinin altında; ancak, vahşi tip suşlara kıyasla daha yüksek olduğu saptanmıştır. Aynı çalışmada vorikonazol ile önceden karşılaşmış olmanın bu polimorfizmi 
taşıyan izolatların genotipik dağılımları üzerinde istatistiksel olarak anlamlı seçici baskı oluşturduğu gösterilmiştir.

Öte yandan CYP51A proteinin üç boyutlu yapısal modellemelerinin oluşturulduğu bir çalışmada, azol direnci ile yakından ilişkilendirilen $\mathrm{L} 98 \mathrm{H}$ veya $\mathrm{M} 220$ gibi aminoasit değişikliklerinin, proteinin azol ya da hem bağlantı noktalarında olduğu, bu nedenle bu değişikliklerin in vitro ve in vivo dirence neden olduğu ortaya konmuştur. Aynı çalışmada, Y46F, G89G, V172M, T248N, E255D, L358L, K427E, C454C değiş̧ikliklerinin ise protein dış bölgelerinde oluştuğu, proteinin yapısal bütünlüğü veya azol bağlanma bölgesi ile ilişkisiz olduğu bildirilmiştir ${ }^{32}$. Benzer olarak Snelders ve arkadaşları protein homoloji modelleme ile azol direncini araştırdıkları bir çalışmada ${ }^{24}$, bu değişikliklerin CYP51A proteinin dış bölgelerinde olduğunu, korunmuş bölgede bulunmadığını ve proteinin biyolojik aktivitesine etkisinin olmadığını göstermişlerdir. Bu polimorfizmin direnç ile ilişkisinin aydınlatılabilmesi için duyarlı ve dirençli izolatların birlikte değerlendirildiği geniş çaplı çalışmalara ihtiyaç duyulmaktadır. Antifungal duyarlılık testleri ve Sanger dizileme yöntemiyle yapılan çalışmalar ise genotip-fenotip ilişkisini yansıtmakta yetersiz kalabilmektedir. Literatürde direnç-virülans ilişkisi yönünden birçok mikroorganizma için gösterildiği gibi, azol dirençli izolatların virülans kaybına uğradığına ilişkin bildirimler de bulunmaktadır ${ }^{33}$. Polimorfizm saptanan bu izolatların dirençli izolatlara benzer şekilde virülans açısından da değerlendirildiği yeni çalışmalar gereklidir.

A.fumigatus'ta azol direnci cyp51A geninden bağımsız mekanizmalarla da oluşabilmektedir. Çalışmamızda, cyp51A geninin incelendiği izolatlarda direnç ile kesin ilişkili kabul edilen mutasyonların hiçbiri saptanmamıştır. Bu bulgu, cyp51A geninde saptanan polimorfizme ek olarak, farklı bir direnç mekanizmasının varlığı ile ilgili olasılığı akla getirmektedir. Bu olası mekanizmaların en önemlilerinden biri ATP bağlayan kaset taşıyıcıları $(A B C)$ veya majör fasilitatör süper ailesi (MFS) gibi dışa atım pompası sistemleri aracılığıyla hücre içinde ilaç konsantrasyonunun azalmasıdır. Bu konuda yapılan sınırlı sayıda çalışmada, A.fumigatus atrF pompası itrakonazol direnci ile ilişkilendirilmiştir ${ }^{34}$. Ayrıca, sterol metabolizması ile ilişkili transkripsiyon faktörlerinden SrbA ve HapE proteinlerinin azol direnci ile bağlantısını gösteren çalışmalar da bulunmaktadır ${ }^{35}$. Gelecekte tüm genom dizileme yönteminin daha yaygın kullanılması ile yeni tanımlanmış direnç mekanizmalarının aydınlatılması ve cyp51A geninden bağımsız olarak gelişen azol direncinin nedenlerinin ortaya çıkarılması mümkün olabilecektir.

Sonuç olarak, çalışmamızda klinik ve çevresel A.fumigatus sensu stricto izolatlarında azol duyarlıık durumu belirlenmiştir. Klinik suşlarda itrakonazole dirençli olan izolat oranının \%2.3 olduğu ve bu oranın ülkemizden başka bir merkezden daha önce rapor edilen orana göre önemli ölçüde düşük olduğu gözlenmiştir. Bu çalışmada çevresel örneklerde, azol tarama plaklarında ve mikrodilüsyon testlerinde azol grubu ilaçlara karşı azalmış duyarlılık gösteren A.fumigatus izolatları da elde edilmiştir. Ancak, bu izolatların bölgesel olarak çok küçük bir alandan toplanmış olması nedeniyle, tek bir klonun tekrarlayan izolasyonunun muhtemel olabileceği düşünülmüştür. Bu çalışmada, çevresel izolatların genotipik yakın- 
lıkları moleküler yöntemlerle analiz edilmemiştir. Çalışmamızda, azol Mik değeri yüksek ve düşük bir grup izolatta cyp51A mutasyonları araştırılmış ve literatürde direnç ile ilişkisi gösterilen mutasyonlara rastlanmamıştır. Öte yandan, hem azol MiK değeri yüksek olan izolatlarda hem de azole duyarlı suşta cyp51A geninde azol direnci ile ilişkisi kesin olarak gösterilmemiş bazı polimorfizmler saptanmıştır. Bu polimorfizmlerin direnç durumu ile ilişkisinin anlaşılabilmesi için, tüm genom analizi çalışmalarının yararlı olabileceği düşünülmüştür. Azol direnci saptanan tüm izolatlarda mutasyon analizi yapılamamış olmasına karşın, literatürde sıklıkla bildirilmiş azol direnci ile ilişkili mutasyonlara rastlanmamış olması, ülkemiz için geçerli olan direnç mekanizmalarının araştırılmasının gerekli olacağını düşündürmüştür. Bu nedenle, ülkemizden klinik izolatlarda yüksek direnç oranı bildiren bir raporun mevcut olduğu da göz önüne alındığında, farklı coğrafi bölgelerimizden elde edilen klinik ve çevresel Aspergillus izolatlarında azol duyarlılığının taranması ve direnç mekanizmalarının ortaya konması için çok merkezli ulusal çalışmaların gerekli olduğu sonucuna varılmıştır.

\section{TEŞEKKÜR}

Çalışmamıza pozitif kontrol olarak dahil edilen TR34/L98H direnç genotipi gösteren 12868 suşu temin etmesi nedeniyle Prof. Dr. Beyza Ener'e teşekkür ederiz.

\section{ÇIKAR ÇATIŞMASI}

Yazarlar bu makale ile ilgili herhangi bir çıkar çatışması bildirmemişlerdir.

\section{KAYNAKLAR}

1. Ruping MJ, Vehreschild JJ, Cornely OA. Patients at high risk of invasive fungal infections: when and how to treat. Drugs 2008; 68(14): 1941-62.

2. McCormick A, Loeffler J, Ebel F. Aspergillus fumigatus: contours of an opportunistic human pathogen. Cell Microbiol 2010; 12(11): 1535-43.

3. Kosmidis C, Denning DW. The clinical spectrum of pulmonary aspergillosis. Thorax 2015; 70(3): $270-7$.

4. Sugui JA, Kwon-Chung KJ, Juvvadi PR, Latge JP, Steinbach WJ. Aspergillus fumigatus and related species. Cold Spring Harb Perspect Med 2014; 5(2): a019786.

5. Alcazar-Fuoli L, Mellado E, Alastruey-Izquierdo A, Cuenca-Estrella M, Rodriguez-Tudela JL. Aspergillus section Fumigati: antifungal susceptibility patterns and sequence-based identification. Antimicrob Agents Chemother 2008; 52(4): 1244-51.

6. Lamoth F. Aspergillus fumigatus-related species in clinical practice. Front Microbiol 2016; 7: 683.

7. Mortensen KL, Mellado E, Lass-Flörl C, Rodriguez-Tudela JL, Johansen HK, Arendrup MC. Environmental study of azole-resistant Aspergillus fumigatus and other Aspergilli in Austria, Denmark, and Spain. Antimicrob Agents Chemother 2010; 54(11): 4545-9.

8. Ullmann AJ, Aguado JM, Arikan-Akdagli S, Denning DW, Groll AH, Lagrou K, et al. Diagnosis and management of Aspergillus diseases: executive summary of the 2017 ESCMID-ECMM-ERS guideline. Clin Microbiol Infect 2018; 24 (Suppl 1): e1-e38.

9. Patterson TF, Thompson GR $3^{\text {rd }}$, Denning DW, Fishman JA, Hadley S, Herbrecht R, et al. Practice guidelines for the diagnosis and management of aspergillosis: 2016 update by the Infectious Diseases Society of America. Clin Infect Dis 2016; 63(4): e1-e60.

10. Vermeulen E, Cooreman S, Maertens J, Jeurissen A, Lagrou K. Azole resistance in Aspergillus: an emerging problem? Acta Clinica Belgica 2012; 67(5): 322-7. 
11. Denning DW, Venkateswarlu K, Oakley KL, Anderson MJ, Manning NJ, Stevens DA, et al. Itraconazole resistance in Aspergillus fumigatus. Antimicrob Agents Chemother 1997; 41(6): 1364-8.

12. Garcia-Rubio R, Cuenca-Estrella M, Mellado E. Triazole resistance in Aspergillus species: an emerging problem. Drugs 2017; 77(6): 599-613.

13. Snelders E, van der Lee HA, Kuijpers J, Rijs AJ, Varga J, Samson RA, et al. Emergence of azole resistance in Aspergillus fumigatus and spread of a single resistance mechanism. PloS Med 2008; 5(11): e219.

14. Verweij PE, Snelders E, Kema GH, Mellado E, Melchers WJ. Azole resistance in Aspergillus fumigatus: a sideeffect of environmental fungicide use? Lancet Infect Dis 2009; 9(12): 789-95.

15. Alanio A, Cabaret O, Sitterle E, Costa JM, Brisse S, Cordonnier C, et al. Azole preexposure affects the Aspergillus fumigatus population in patients. Antimicrob Agents Chemother 2012; 56(9): 4948-50.

16. Hagiwara D, Watanabe A, Kamei K, Goldman GH. Epidemiological and genomic landscape of azole resistance mechanisms in Aspergillus fungi. Front Microbiol 2016; 7: 1382.

17. Larone DH. Medically Important Fungi: A Guide to Identification. 2011, $5^{\text {th }}$ ed. ASM Press, Washington, DC.

18. Arendrup MC, Verweij PE, Mouton JW, Lagrou K, Meletiadis J. Multicentre validation of 4-well azole agar plates as a screening method for detection of clinically relevant azole-resistant Aspergillus fumigatus. J Antimicrob Chemother 2017; 72(12): 3325-33.

19. Arendrup MC, Lass-Flörl C, Hope W, Howard SJ, Subcommittee on Antifungal Susceptibility Testing (AFST) of the ESCMID European Committee for Antimicrobial Susceptibility Testing. EUCAST definitive document EDef 9.2. Method for the determination of broth dilution minimum inhibitory concentrations of antifungal agents for conidia forming moulds. EUCAST, 2014. Basel, Switzerland.

20. Ozmerdiven GE, Ak S, Ener B, Agca H, Cilo BD, Tunca B, et al. First determination of azole resistance in Aspergillus fumigatus strains carrying the TR34/L98H mutations in Turkey. J Infect Chemother 2015; 21(8): 581-6.

21. van der Linden JWM, Arendrup MC, van der Lee HAL, Melchers WJG, Verweij PE. Azole containing agar plates as a screening tool for azole resistance of Aspergillus fumigatus. Mycoses 2009; 52(Suppl 1): 19.

22. Arendrup MC, Verweij PE, Mouton JW, Lagrou K, Meletiadis J. Multicentre validation of 4-well azole agar plates as a screening method for detection of clinically relevant azole-resistant Aspergillus fumigatus. J Antimicrob Chemother 2018; 73(8): 2274.

23. Guinea J, Verweij PE, Meletiadis J, Mouton JW, Barchiesi F, Arendrup MC, et al. How to: EUCAST recommendations on the screening procedure E.Def 10.1 for the detection of azole resistance in Aspergillus fumigatus isolates using four-well azole-containing agar plates. Clin Microbiol Infect 2019; 25(6): 681-7.

24. Snelders E, Karawajczyk A, Schaftenaar G, Verweij PE, Melchers WJ. Azole resistance profile of amino acid changes in Aspergillus fumigatus CYP51A based on protein homology modeling. Antimicrob Agents Chemother 2010; 54(6): 2425-30.

25. Rivero-Menendez O, Alastruey-Izquierdo A, Mellado E, Cuenca-Estrella M. Triazole resistance in Aspergillus spp.: a worldwide problem? J Fungi (Basel) 2016; 2(3): 21.

26. Verweij PE, Lestrade PP, Melchers WJ, Meis JF. Azole resistance surveillance in Aspergillus fumigatus: beneficial or biased? J Antimicrob Chemother 2016; 71(8): 2079-82.

27. Denning DW, Perlin DS. Azole resistance in Aspergillus: a growing public health menace. Future Microbiol $2011 ; 6(11): 1229-32$.

28. Snelders E, Huis In 't Veld RA, Rijs AJ, Kema GH, Melchers WJ, Verweij PE. Possible environmental origin of resistance of Aspergillus fumigatus to medical triazoles. Appl Environ Microbiol 2009; 75(12): 4053-7.

29. Wiederhold NP, Patterson TF. Emergence of azole resistance in Aspergillus. Semin Respir Crit Care Med 2015; 36(5): 673-80.

30. Alvarez-Moreno C, Lavergne RA, Hagen F, Morio F, Meis JF, Le Pape P. Azole-resistant Aspergillus fumigatus harboring TR34/L98H, TR46/Y121F/T289A and TR53 mutations related to flower fields in Colombia. Sci Rep 2017; 7: 45631. 
31. Escribano P, Recio S, Pelaez T, Bouza E, Guinea J. Aspergillus fumigatus strains with mutations in the cyp51A gene do not always show phenotypic resistance to itraconazole, voriconazole, or posaconazole. Antimicrob Agents Chemother 2011; 55(5): 2460-2.

32. Liu M, Zheng N, Li D, Zheng H, Zhang L, Ge H, et al. cyp51A-based mechanism of azole resistance in Aspergillus fumigatus: illustration by a new 3D structural model of Aspergillus fumigatus CYP51A protein. Med Mycol 2016; 54(4): 400-8.

33. Arendrup MC, Mavridou E, Mortensen KL, Snelders E, Frimodt-Moller N, Khan H, et al. Development of azole resistance in Aspergillus fumigatus during azole therapy associated with change in virulence. PloS One 2010; 5(4): e10080.

34. Slaven JW, Anderson MJ, Sanglard D, Dixon GK, Bille J, Roberts IS, et al. Increased expression of a novel Aspergillus fumigatus $\mathrm{ABC}$ transporter gene, atrF, in the presence of itraconazole in an itraconazole resistant clinical isolate. Fungal Genet Biol 2002; 36(3): 199-206.

35. Willger SD, Puttikamonkul S, Kim KH, Burritt JB, Grahl N, Metzler LJ, et al. A sterol-regulatory element binding protein is required for cell polarity, hypoxia adaptation, azole drug resistance, and virulence in Aspergillus fumigatus. PloS Pathog 2008; 4(11): e1000200. 